\title{
Salivary $\alpha$-Amylase of Stem Borer Hosts Determines Host Recognition and Acceptance for Oviposition by Cotesia spp. (Hymenoptera, Braconidae)
}

\author{
Gladys B. Bichang'a ${ }^{1,2 *}$, Jean-Luc Da Lage ${ }^{3}$, Kevin Sambai ${ }^{1}$, Simon Mule ${ }^{1}$, Bruno Le Ru ${ }^{1,3}$, \\ Laure Kaiser ${ }^{3}$, Gerald Juma ${ }^{2}$, Esther N. Maina ${ }^{2}$ and Paul-André Calatayud ${ }^{1,3 *}$ \\ ${ }^{1}$ International Centre of Insect Physiology and Ecology (icipe), Nairobi, Kenya, ${ }^{2}$ Department of Biochemistry, University of \\ Nairobi, Nairobi, Kenya, ${ }^{3}$ Evolution, Génomes, Comportement, Ecologie, CNRS, IRD, University Paris-Sud, Université \\ Paris-Saclay, Gif-sur-Yvette, France
}

OPEN ACCESS

Edited by:

Gordon M. Bennett, University of California, Merced, United States

Reviewed by:

Mark G. Wright,

University of Hawaii at Manoa,

United States

Angela Poole,

Berry College, United States

*Correspondence:

Gladys B. Bichang'a

gbichanga@uonbi.ac.ke

Paul-André Calatayud

pcalatayud@icipe.org

Specialty section:

This article was submitted to

Coevolution,

a section of the journal

Frontiers in Ecology and Evolution

Received: 22 June 2018 Accepted: 07 December 2018

Published: 19 December 2018

Citation:

Bichang'a GB, Da Lage J-L, Sambai K, Mule S, Le Ru B, Kaiser L, Juma G, Maina EN and Calatayud P-A

(2018) Salivary $\alpha$-Amylase of Stem Borer Hosts Determines Host

Recognition and Acceptance for Oviposition by Cotesia spp.

(Hymenoptera, Braconidae).

Front. Ecol. Evol. 6:228.

doi: 10.3389/fevo.2018.00228
Foraging insect parasitoids use specific chemical cues to discriminate between host and non-host species. Several compounds have been identified in "host location and acceptance." However, nothing is known about the molecular variations in these compounds that could account for host-range differences between parasitoid species. In a previous study, it was shown that during the host-finding process, contact between the braconid Cotesia flavipes and its host is crucial, and that $\alpha$-amylase of oral secretions from the host plays a key role for host acceptance and oviposition by the parasitoid. The present study sought to establish whether the variations in this enzyme could explain specific host recognition in different host-parasitoid associations. Different species and populations of the $C$. flavipes complex specialized on graminaceous lepidopteran stemborers were used. Electrophoresis of $\alpha$-amylase revealed different isoforms that mediate the parasitoid's oviposition acceptance and preference for a specific host. This discovery opens up new avenues for investigating the evolutionary processes at play in chemically-mediated host specialization in the species-rich Cotesia genus.

Keywords: parasitic wasp, Cotesia flavipes, Cotesia sesamiae, Cotesia typhae, protein perception, host specificity, oviposition

\section{INTRODUCTION}

Parasitoids comprise the major biological control agents of pest insects (Pimentel et al., 1992; Tilman et al., 2001; Lazarovitz et al., 2007; Godfray et al., 2010). Among them, the Hymenoptera order contains the most diversified species: 50,000 in Hymenoptera, compared with only 15,000 in Diptera, and 3,000 in other orders (Quicke, 1997). To reproduce successfully, the parasitoids need to overcome the behavioral and physiological defenses of their hosts (Kaiser et al., 2017a). The hosts' defense mechanisms, which co-evolved with the parasitoids, may be linked to host range changes and the appearance of host races within different parasitoid species (Kaiser et al., 2017a). These underlying mechanisms provide insight into evolutionary biology, and they might improve the selection of parasitoids in bio-control.

The ability of parasitoids to efficiently utilize cues from their habitat and to efficiently distinguish suitable from unsuitable hosts, determines their field efficiency (Wajnberg et al., 2008; 
Wajnberg and Colazza, 2013). When locating hosts, they first use long (i.e., from a distance) and short-range chemicals coming from the host habitat, and secondly those directly present on the host and on its feeding products (Wajnberg et al., 2008; Wajnberg and Colazza, 2013). However, long-range chemicals from the habitat do not generally give them sufficiently reliable information about the host's suitability (Vet, 1999). In contrast, those directly present on the host and on its feeding products are directly used during host-contact evaluation by the parasitoids. These chemicals generally allow them to assess the quality and status of the herbivore's suitability (Lewis and Martin, 1990; Vinson, 1991; Godfray, 1994; Wajnberg et al., 2008; Wajnberg and Colazza, 2013). Moreover, the structure and quantity of these semiochemicals, which vary according to the host's species, the developmental stage of the host, the host's size, condition, and diet, influence host acceptance and selection by the parasitoids (Vinson, 1991; Röse et al., 1997; Wajnberg et al., 2008; Wajnberg and Colazza, 2013).

Among parasitoids, Cotesia is one of the most diverse genera in the Braconidae family (Kaiser et al., 2017a). Many Cotesia species may appear to have broad host ranges, but careful ecological studies have revealed a hidden complexity with an assemblage of populations with more restricted host ranges (Branca et al., 2011; Kaiser et al., 2017b). Whereas recent studies revealed that variations in virulence genes account for differences in host range and in the degree of specialization toward a host (Gauthier et al., 2018), almost nothing is known about the variations in functions involved in specific host recognition and acceptance.

The Cotesia flavipes species-monophyletic group is composed of four sister species: C. chilonis (Matsumura), C. flavipes Cameron, C. nonagriae (Olliff), and C. sesamiae (Cameron). They are all gregarious endoparasitoids of crambid, pyralid and noctuid stem borers feeding on Poaceae, Typhaceae, and Cyperaceae species (Kaiser et al., 2017b). These small wasps, after mating, lay egg(s) in a host's body (generally a caterpillar). To inhibit the immune response of the caterpillars, they use a domesticated virus called bracovirus (PolyDNA virus). These viruses are located in the wasp ovaries and are integrated into the genome of the wasp and injected into the caterpillar together with the eggs during the parasitism process (see Kaiser et al., 2017a for review).

Cotesia flavipes Cameron is widespread in Asia and was introduced into Africa to control the invasive Asian crambid Chilo partellus Swinhoe (Overholt et al., 1994a,b). It parasitizes the larvae of more than 30 Lepidoptera species, including the crambids C. partellus and Chilo suppressalis (Walker), as well as the African noctuid Sesamia calamistis Hampson, a new association host (https://www.cabi.org/isc/datasheet/5951). The C. flavipes population brought into Africa for classical biological control was specific to C. partellus in Asia (Muirhead et al., 2012). Cotesia sesamiae is widespread in Sub-Saharan Africa and is commonly found on Busseola fusca and S. calamistis (Kfir, 1995; Kfir et al., 2002), but its parasitism success greatly depends on the host species and parasitoids populations (Mochiah et al., 2002; Gitau et al., 2010). Two factors contribute to the differences and hence to the performance of $C$. sesamiae populations on stem borer pests across Africa, namely, the symbiotic polyDNA viruses, which are responsible for the differences in virulence of C. sesamiae population on B. fusca (Gitau et al., 2010), and the bacteria Wolbachia, by creating cytoplasmic incompatibilities between populations of C. sesamiae populations (Mochiah et al., 2002). In contrast to the $C$. sesamiae population from Mombasa/coastal Kenya (Cs-Coast), the $C$. sesamiae population from Kitale/inland Kenya (Cs-Inland) is able to develop in $B$. fusca, which is predominant in the highlands, whereas both are able to develop in the noctuid S. calamistis, the main host of C. sesamiae population from Mombasa/coastal Kenya (Ngi-Song et al., 1995). The Cs-Inland is mostly present in the highlands and wet regions, where its host $B$. fusca occurs, and is absent in the dry and warmer regions, where Cs-Coast and C. flavipes predominate (Mailafiya et al., 2010; Mwalusepo et al., 2015). The genetic diversity of these C. sesamiae populations, especially regarding their relationships with spatial, biotic, and abiotic ecological factors, is reported by Branca et al. (2018). The authors highlighted the importance of host forces in the evolution of the diversity of parasitoid-host interactions.

Cotesia sesamiae and C. flavipes locate their host at a distance by the emission of volatiles from the plants infested by their hosts. However, these volatiles do not convey reliable information on host suitability but are simply indicators of the presence of herbivores in the plant. As a result, C. sesamiae and $C$. flavipes might be attracted to plants infested by unsuitable Lepidoptera stemborers (Potting et al., 1993, 1995; Ngi-Song et al., 1996; Obonyo et al., 2008). It is only when approaching and touching the host that C. sesamiae and C. flavipes are able to identify their hosts properly, relying on specific host-produced signals. The signals particularly arise from oral secretions, which give reliable information on the host identity perceived by the tactile and contact-chemoreception of the parasitoid (Obonyo et al., 2010a,b). These authors observed that host selection and acceptance by the parasitoid females for parasitism is characterized by two behavioral steps: drumming the body of the host with the antennae (antennation), followed by an attempt to oviposit into the host. Recently, Bichang'a et al. (2018) showed that $\alpha$-amylase present in the oral secretions of C. partellus larvae mediates these behavioral responses of $C$. flavipes. The present study investigates whether $\alpha$-amylase presents variations which allow for recognition and selection of host species or population in Cotesia spp. using the two populations of C. sesamiae living in Kenya with their respective hosts B. fusca and S. calamistis, as well as a new species of Cotesia described recently as $C$. typhae Fernandez-Triana sp., parasitizing Sesamia nonagrioides (Lefèbvre) (Lepidoptera, Noctuidae) (Kaiser et al., 2017a), and the introduced C. flavipes and its old association host C. partellus.

\section{MATERIALS AND METHODS}

\section{Insect Rearing}

Females of $C$. flavipes, an inland and coastal population of $C$. sesamiae (hereafter named Cs-Inland and Cs-Coast, respectively), as well as that of $C$. typhae, came from laboratory-reared colonies established at icipe, Nairobi, Kenya. Cotesia flavipes was initially obtained in 2005 from C. partellus larvae collected 
TABLE 1 | Suitability of lepidopteran stem borer species to different Cotesia species and strains based on field observations and the literature.

\begin{tabular}{|c|c|c|c|c|}
\hline & $\begin{array}{c}\text { Chilo } \\
\text { partellus }\end{array}$ & $\begin{array}{c}\text { Busseola } \\
\text { fusca }\end{array}$ & $\begin{array}{l}\text { Sesamia } \\
\text { calamistis }\end{array}$ & $\begin{array}{c}\text { Sesamia } \\
\text { nonagrioides }\end{array}$ \\
\hline Cotesia flavipes & 0 & W & new & non \\
\hline \multicolumn{5}{|l|}{ Cotesia sesamiae } \\
\hline Cs-Inland & w & $\mathrm{O}$ & O & non \\
\hline Cs-Coast & new & W & $\mathrm{O}$ & non \\
\hline Cotesia typhae & non & non & w & 0 \\
\hline
\end{tabular}

A code was attributed to indicate the level of host suitability, where non, non-host; w, "weak" host association; new, new host association; o, old host association.

from maize fields in Mombasa, coastal Kenya. Cs-Inland was initially obtained in 2006 from B. fusca larvae infesting maize fields in Kitale, Western Kenya, while the Cs-Coast was initially obtained in 2007 from S. calamistis larvae infesting maize fields in Mombasa (coastal Kenya). Cotesia typhae was initially obtained in 2013 from S. nonagrioides larvae infesting Cyperus dives at Kobodo near Lake Victoria, Kenya.

Cotesia flavipes, Cs-Inland, Cs-Coast, and C. typhae were continuously reared on larvae of C. partellus, B. fusca, S. calamistis, and $S$. nonagrioides, respectively, as previously described by (Overholt et al., 1994a). Twice a year, all colonies were rejuvenated by field-collected parasitoids.

For each colony, the cocoons were kept until emergence. After emergence, adult parasitoids were fed on a $20 \%$ honey/water solution and placed under artificial light for $8 \mathrm{~h}$ to mate. In all the behavioral bioassays, 1-day-old naïve (i.e., without oviposition experience), mated females were used. Similar to Overholt et al. (1994a), experimental conditions were at $25 \pm 2{ }^{\circ} \mathrm{C}$, at $50-80 \%$ relative humidity $(\mathrm{RH})$ and with a $12: 12 \mathrm{~h}(\mathrm{~L}: \mathrm{D})$ photoperiod.

Different host species that varied in their suitability according to the Cotesia species and strains were used (Table 1). Old host association (=natural host) was defined according to both the origin of the parasitoid and the host (Table 1). For example, $C$. partellus is considered an old host association, since this host is from the same origin of the parasitoid in Asia (Overholt et al., 1994b) and was parasitizing this host before its introduction into Africa, whereas the African S. calamistis is a new association.

Chilo partellus and S. calamistis were initially collected from maize fields in coastal regions of Kenya, and B. fusca from maize fields in Western Kenya (Kitale), while S. nonagrioides were initially collected from Typha domingensis in Makindu, Kenya. The larvae of $C$. partellus were continuously reared at icipe on artificial diets of Ochieng et al. (1985), whereas the larvae of the other species were fed on the artificial diet of Onyango and Ochieng'-Odero (1994). Twice a year, all host's colonies were rejuvenated by field-collected stemborer larvae. Table 1 gives the host-parasitoid species and strains associations.

\section{Collection of Oral Secretions From Host Larvae}

Acceptance of host larvae for oviposition by Cotesia parasitoids is enhanced when the host larvae are fed on maize stems for
$24 \mathrm{~h}$ prior to exposure to parasitism (Mohyuddin et al., 1981; Inayatullah, 1983; Van Leerdam et al., 1985; Potting et al., 1993; Overholt et al., 1994a), most likely because more $\alpha$-amylase can be found in the oral secretion from larvae after feeding on maize stems than on artificial diets (Bichang'a et al., 2018). Therefore, $\alpha$-amylase was isolated from third and fourth instar larvae previously fed for $24 \mathrm{~h}$ on maize stems. Each larva was squeezed by soft forceps behind the head to collect its oral secretion into a capillary tube and was immediately transferred to an Eppendorf tube which had been placed on ice. This was repeated for at least 100-200 larvae per species to get a sufficient amount of oral secretion (about $500-800 \mu \mathrm{L}$ per species), estimated by weighing. All samples were preserved at $-80^{\circ} \mathrm{C}$ until further use.

\section{Purification of the $\alpha$-Amylases}

The oral secretions were first centrifuged at $11,000 \times \mathrm{g}$ for $5 \mathrm{~min}$ in order to remove the undetected debris (grass and undigested food materials). About $600-800 \mu \mathrm{L}$ of supernatant was transferred to a clean tube and the proteins precipitated using ammonium sulfate salt. To the supernatant, ammonium sulfate salt was gradually added to a final salt saturation of $90 \%$ and precipitated overnight at $4^{\circ} \mathrm{C}$. The proteins were subsequently pelleted by centrifugation at $12,000 \times \mathrm{g}$ for $1 \mathrm{~h}$ at $4^{\circ} \mathrm{C}$ and were then resuspended in HEPES- $\mathrm{NaCl}$ buffer (HEPES $20 \mathrm{mM}, \mathrm{NaCl}$ $20 \mathrm{mM}, \mathrm{CaCl}_{2} 1 \mathrm{mM}, \mathrm{pH}$ 7.5) and dialyzed (MWCO 12-14000 $\mathrm{Da}$ ) overnight at $4^{\circ} \mathrm{C}$ in the same buffer.

The $\alpha$-amylase was purified using the glycogen-amylase complex precipitation method described by Loyter and Schramm (1962) with some modifications. Briefly, ice-cold absolute ethanol was added dropwise $(2 / 3 \mathrm{v} / \mathrm{v})$ to the dialyzed samples placed on ice and mixed for $40 \mathrm{~min}$ at $4^{\circ} \mathrm{C}$. This mixture was centrifuged at $20,000 \mathrm{rpm}$ for $30 \mathrm{~min}$ at $4^{\circ} \mathrm{C}$ to pellet the nucleic acids. To the supernatant, glycogen (Sigma Aldrich) was added to a final concentration of $2.4 \mathrm{mg} / \mathrm{ml}$ per sample and mixed for $20 \mathrm{~min}$ for $S$. calamistis and $S$. nonagrioides, and $5 \mathrm{~min}$ for $B$. fusca and C. partellus at $4^{\circ} \mathrm{C}$ (As observed in previous assays; the different timings allowed for optimum yield of $\alpha$-amylases). Subsequently, the mixtures were centrifuged for $20 \mathrm{~min}$ at 20,000 $\mathrm{rpm}$ at $4^{\circ} \mathrm{C}$ to pellet the amylase-substrate complex, and the pellets were dissolved in the aforementioned HEPES-NaCl buffer. The amylase-substrate complexes were left on the bench for $3 \mathrm{~h}$ at room temperature to digest the glycogen in the complexes. The remaining $\alpha$-amylases were dialyzed (MWCO 12-14000 $\mathrm{Da}$ ) overnight against the same buffer and kept at $-20^{\circ} \mathrm{C}$ for electrophoresis and bioassays.

\section{Native PAGE and $\alpha$-Amylase zymogram}

For the $\alpha$-amylases of each host species, electrophoresis was conducted under non-denaturing conditions (native PAGE electrophoresis) as follows: For each host species, ten microliters of purified $\alpha$-amylase were mixed separately with $10 \mu \mathrm{L}$ buffer $(50 \mathrm{mM}$ tris- $\mathrm{HCl}, \mathrm{pH} 6.8,10 \%$ glycerol (v/v), and 1\% bromophenol blue) and electrophoresed in the Ornstein-Davis discontinuous buffer system on a $7.5 \%$ native polyacrylamide gel at $4^{\circ} \mathrm{C}$ according to Schrambach and Jovin (1983) and Niepmann and Zheng (2006). After running the gel at a 
constant voltage of $150 \mathrm{~V}$ and a current of $25 \mathrm{~mA}$ for $1 \mathrm{~h}$, and when the dye-containing sample reached the bottom of the glass, the polyacrylamide gel was stained according to Nagaraju and Abraham (1995) with minor modifications. The gel was incubated for $1 \mathrm{~h}$ at $37^{\circ} \mathrm{C}$ in $1 \%$ soluble potato starch (Sigma Aldrich) and $1 \mathrm{M} \mathrm{CaCl}_{2}$, washed thoroughly with $\mathrm{ddH}_{2} \mathrm{O}$ and subsequently stained with $0.1 \%$ of Lugol's iodine solution $\left(\mathrm{I}_{3} \mathrm{~K}\right)$ until white bands against a blue background were visible. The proteins were compared to a molecular mass standard (Sigma Aldrich) containing albumin from bovine serum (Sigma A8654, $132 \mathrm{kDa}$ ), albumin from chicken egg white (Sigma A8529, 45 $\mathrm{kDa}$ ), and $\alpha$ lactalbumin from bovine milk (Sigma L4385, 14.2 $\mathrm{kDa}$ ). The gel images were acquired using the myECL ${ }^{\mathrm{TM}}$ Imager (Thermo) and analyzed using myImageAnalysis ${ }^{\mathrm{TM}}$ Software (Thermo).

It was previously observed that the concentration of $\alpha$-amylase in the extract conditioned the behavioral response of the wasp (Bichang'a, 2018; Bichang'a et al., 2018).

For each host species, the concentration of $\alpha$-amylase was estimated using a calibration electrophoretic migration obtained from increasing concentrations of between 50 and $1000 \mu \mathrm{g} / \mathrm{mL}$ of $\alpha$-amylase of Aspergillus oryzae from Sigma No A9857 and of D. melanogaster produced on the Pichia pastoris yeast (Figure S1). This calibration electrophoretic migration did not lead us to a precise amount of $\alpha$-amylase but rather to a range of concentrations. Moreover, it was observed that the optimal range of concentrations of $\alpha$-amylase to induce host recognition and acceptance for oviposition behaviors by the parasitoids was 300-500 $\mu \mathrm{g} / \mathrm{ml}$ (Bichang'a, 2018; Bichang'a et al., 2018). For each of the host species, the concentrations of $\alpha$ amylase used for the subsequent bioassays was adjusted at 300$500 \mu \mathrm{g} / \mathrm{ml}$.

\section{Western Blot Analysis of the Purified $\alpha$-Amylases of Each Host Species}

In order to confirm for each stem borer species that the purified proteins were indeed $\alpha$-amylases, after being used for all bioassays, a western blot was performed using an antibody specific to Drosophila melanogaster Meigen $\alpha$-amylase using the similar protocol of Bichang'a et al. (2018). Ten microliters of each heat denatured protein sample (about $500 \mathrm{ng} / \mu \mathrm{l}$ ) were loaded on a NuPAGE 4-12\% Bis-Tris Gel (Invitrogen) and electrophoresis conducted for $1 \mathrm{~h}$ at 200 volts in a MOPS buffer. The proteins were then transferred to an iBlot Gel Transfer Nitrocellulose membrane (Invitrogen) using the iBlot Gel Transfer Device (Invitrogen). The membrane was washed in $1 \mathrm{X}$ PBS for $20 \mathrm{~min}$, after which it was incubated for $90 \mathrm{~min}$ in a milk solution (1X PBS, $0.1 \%$ Tween, $5 \%$ milk) in order to saturate the membrane with proteins. The membrane was then incubated with the primary anti Drosophila melanogaster $\alpha$-amylase antibody (gift from Dr B. Lemaitre) according to Chng et al. (2014), it was diluted 1,000 -fold in a solution of $1 \mathrm{X}$ PBS, $0.1 \%$ Tween, $1 \%$ milk for several hours. After this step, the membrane was washed six times in $1 \mathrm{X}$ PBS, $0.1 \%$ Tween before incubating with the secondary antibody (anti-guinea pig IgG Peroxidase, Sigma A7289), diluted 1,000-fold in a solution of $1 \mathrm{X}$ PBS, $0.1 \%$
Tween, $1 \%$ milk, for $1 \mathrm{~h}$. The membrane was then washed 3 times in $1 \mathrm{X}$ PBS, $0.1 \%$ Tween. The peroxidase activity was detected using Amersham ECL Prime Western Blotting Detection Reagent (GE Healthcare) and recorded on an Odyssey FC imager.

\section{Behavioral Bioassays}

In this study, the two behavioral steps (antennation + stinging attempt), as shown by Obonyo et al. (2010a,b), were used to confirm host acceptance by Cotesia females for oviposition. To test the behavioral activities triggered by different $\alpha$-amylases, $300-500 \mu \mathrm{g} / \mathrm{ml}$ of $\alpha$-amylases [the minimal concentration found to mediate a positive response of $C$. flavipes (Bichang'a et al., 2018)] were placed on small pieces of cotton wool and presented to female parasitoids. A small piece of cotton wool was rolled into a spherical shape of around $2 \mathrm{~mm}$ in diameter and placed at the center of a Petri dish of $8 \mathrm{~cm}$ in diameter without a cover. About $0.5-1 \mu \mathrm{L}$ of $\alpha$-amylase was deposited on the cotton wool ball. A single female wasp was introduced near the cotton wool and both were covered with a transparent circular Perpex lid $(3 \mathrm{~cm}$ wide, $1 \mathrm{~cm}$ high) to prevent the parasitoid from flying off, and to allow for observations.

The behavior of the parasitoid in the Petri dish was monitored for a maximum of $120 \mathrm{~s}$. For each female, both antennation and stinging attempts were recorded. The percentage of positive responses (i.e., antennation + stinging) was calculated from 30 females tested per type of $\alpha$-amylase. The females, the cotton wool balls with tested $\alpha$-amylase and the arena were replaced after each observation.

According to Obonyo et al. (2010a), all behavioral experiments were carried out in a room at $26 \pm 1^{\circ} \mathrm{C}$ between $10 \mathrm{a}$.m. and 2 p.m. with a constant source of light to maintain an optimal temperature for the behavioral activities of the female parasitoids.

\section{Statistical Analysis}

For each bioassay, Marascuilo's procedure, that is, a pairwise comparison after Pearson's Chi-square test to check the overall significance differences, was used to separate the proportions of wasps that exhibited positive responses (i.e., antennation + stinging attempts) (Marascuilo, 1966).

\section{RESULTS}

The $\alpha$-amylase exhibited species-specific electrophoretic migrations showing different numbers of isoforms using the Lugol test (Figure 1). The $\alpha$-amylase of $C$. partellus exhibited mostly 1 band, whereas $\alpha$-amylase of $B$. fusca appeared to have two main different isoforms, while that of $S$. calamistis exhibited two thick, highly visible isoforms, and three thinner bands between and three faint bands, which migrated much faster than the others. $\alpha$-Amylase of $S$. nonagrioides had three thick groups of isoforms, one thin band and a pair of highly visible thin bands migrating faster. We confirmed by Western blot analysis for $S$. nonagrioides, $S$. calamistis and B. fusca that these were alphaamylase proteins (Figure 2). In the non-denaturing gels stained using iodine at Figure 1, which show white bands where active amylases have migrated, proteins are separated by their electric 


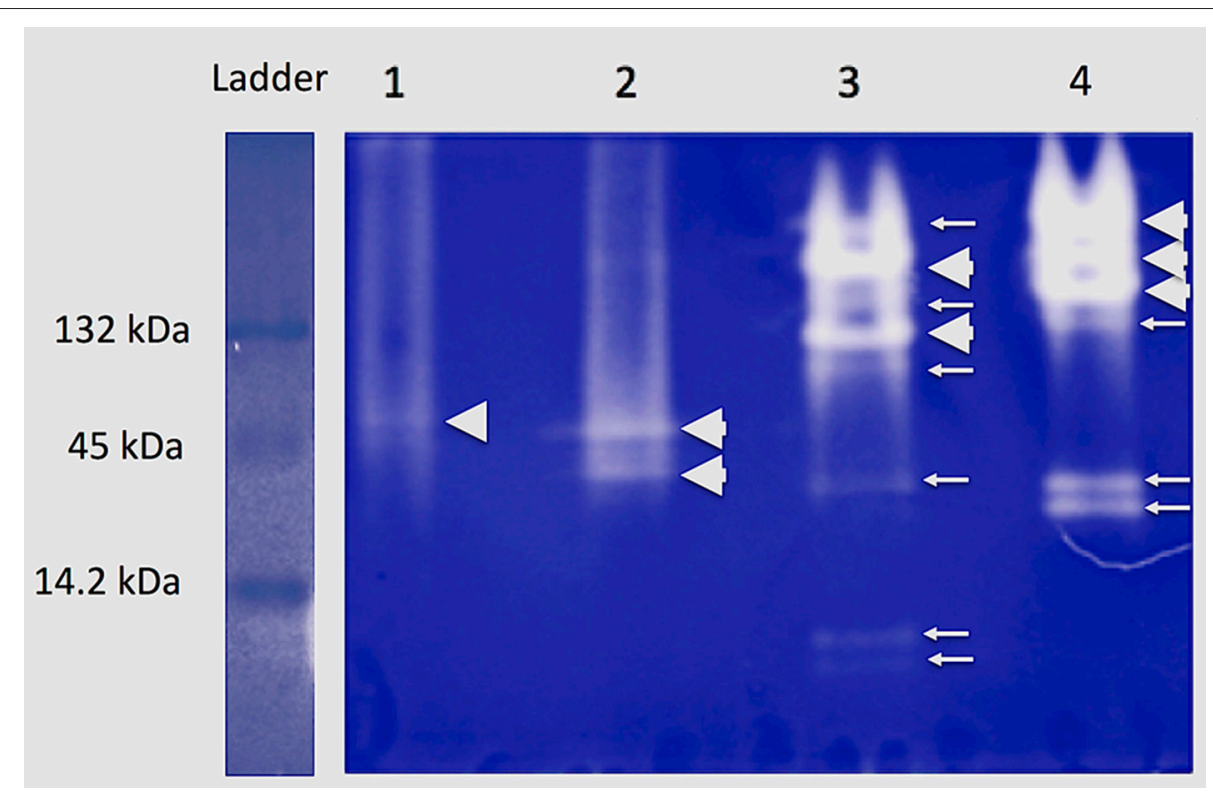

FIGURE 1 | Non-denaturing gel electrophoresis of the amylolytic activity of the purified $\alpha$-amylases from the oral secretions of larvae of Chilo partellus (1), Busseola fusca (2), Sesamia calamistis (3), and Sesamia nonagrioides (4). For each species, the arrows highlight the main isoforms obtained.

charge, which is mostly the result of the difference between (Lys and Arg) and (Asp and Glu) residue numbers. A single gene may exhibit two bands if the two alleles differ in charge. If there are more than two bands, especially if they are separated, e.g., as two pairs of bands, one can infer that there are two active copies. In contrast, in the SDS-PAGE (denaturing) used for Western blot, all the proteins migrate to the same position because they have the same molecular weight. This is the reason why a single labeled band was observed in Figure 2. For a mixture of various proteins, migration of Figure 1 depends on both electric charge and molecular weight (as well as conformation, shape, etc.); but as far as amylases only are concerned, since they all have similar molecular weight, the differences observed in migration distances are due to the differences in electric charges (electromorphs). However, no band was obtained for C. partellus, although $\alpha$-amylase activity was seen in these sample type in Figure 1. The amount of protein sample of the C. partellus used for western blot was lower compared to amounts of the other species. The limit of protein detection was therefore attained for this sample type by Western blot.

For each parasitoid species and strains used in this study, parasitoid females exhibited different behavior according to the origin of the $\alpha$-amylase (C. flavipes: Chi-square $=13.43$; $\mathrm{df}=$ 3, $P=0.0038 ; C s$-Inland: Chi-square $=27.548 ; \mathrm{df}=3, P<$ 0.0001; Cs-Coast: Chi-square $=8.2458 ; \mathrm{df}=3$ and $P=0.04119$ and $C$. typhae: Chi-square $=15.239 ; \mathrm{df}=3$ and $P=0.001623$ ) (Figure 3). For C. flavipes females, $\alpha$-amylases from the larvae of the old association host C. partellus and the new association host $S$. calamistis induced the highest positive responses followed by those from $B$. fusca, whereas those from $S$. nonagrioides larvae did not induce any behavior (Figure 3). For Cs-Inland females, $\alpha$-amylases from the preferred host $B$. fusca induced the highest positive response, followed by those from the suitable $S$. calamistis, whereas those from the unsuitable hosts $C$. partellus and $S$. nonagrioides did not induce any response (Figure 3). For the $C s$-Coast females, $\alpha$-amylases from the suitable new association hosts $C$. partellus and the natural host $S$. calamistis induced higher responses than those from the unsuitable $B$. fusca and $S$. nonagrioides (Figure 3). For the more specific Cotesia species, $\alpha$-amylase from the suitable host $S$. nonagrioides induced a higher response than those from the unsuitable species (Figure 3).

In summary, for each parasitoid species and population there was a strong co-relationship between the behavioral response toward $\alpha$-amylases of the larvae by the parasitoid female (Figure 3) and the level of host suitability (Table 1).

\section{DISCUSSIONS}

This study revealed that the response of female Cotesia to the $\alpha$-amylase from larval oral secretions depended on both the host and parasitoid species or population, with a strong relationship between the level of response and host preference/suitability. Highest responses were observed with the proteins of the old association host (i.e., most suitable host), whereas protein of unsuitable species triggered little or no response. Variations of host $\alpha$-amylase between host species would thus allow specific host recognition and acceptance by the parasitoids.

Lepidopteran stemborers in Africa present high ecological and genetic diversity (Le Ru et al., 2006a,b), characterized by a large number of closely related plant-specific species (Le Ru et al., 2006a,b; Moolman et al., 2014; Ong'amo et al., 2014; Goftishu et al., 2018). Correspondingly, Mailafiya et al. (2009) found a 


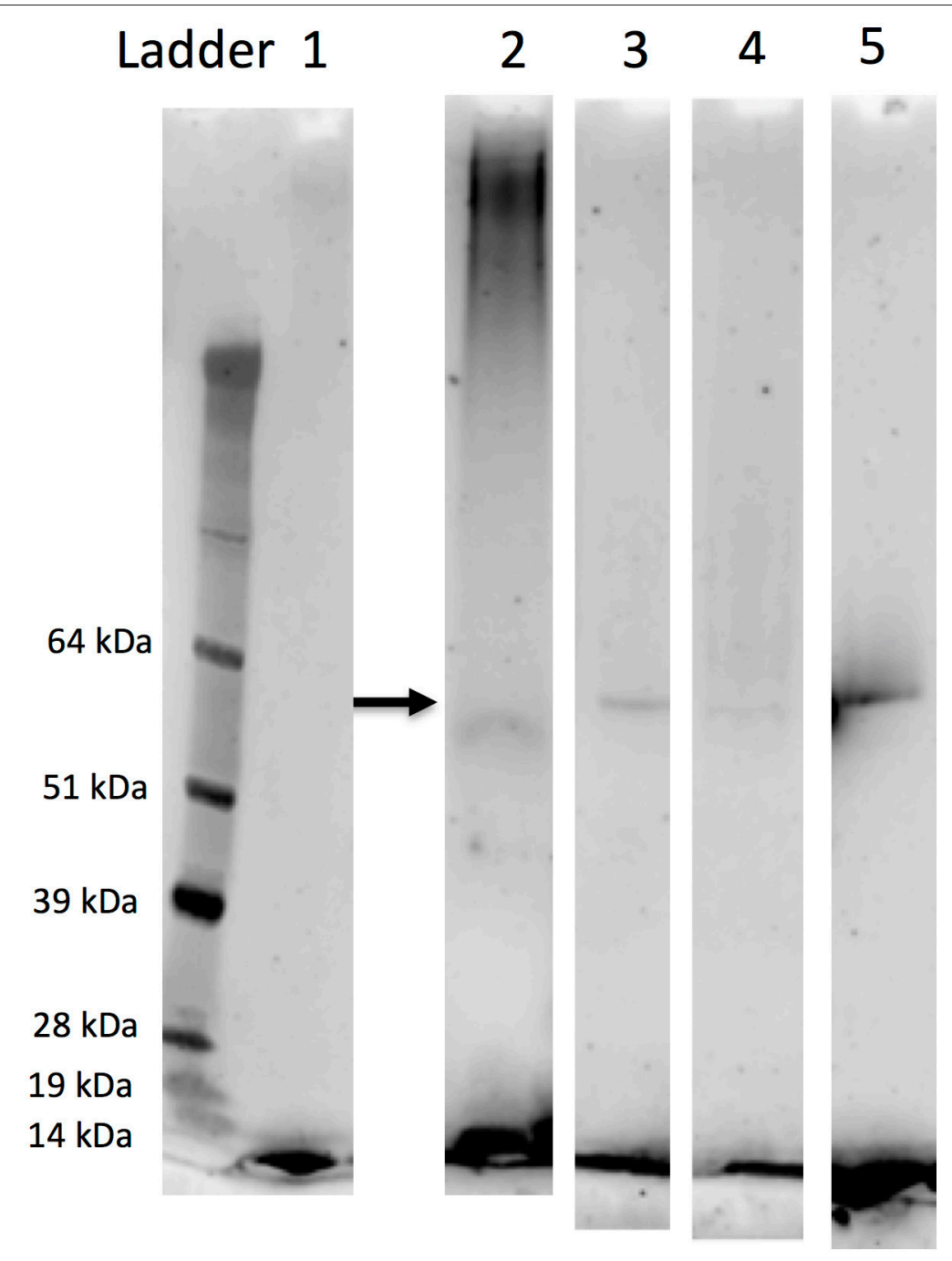

FIGURE 2 | Western blot performed using a Drosophila melanogaster $\alpha$-amylase-specific antibody toward the purified $\alpha$-amylases from the oral secretions of larvae of Chilo partellus (1), Busseola fusca (2), Sesamia calamistis (3), and Sesamia nonagrioides (4). Ladder: molecular weight markers (pre-stained SeeBlue Plus2, Thermo Fischer). 5: $\alpha$-amylase from Drosophila melanogaster.

high diversity of the Cotesia spp., particularly among Busseola spp. and Chilo spp., which also revealed a strong host-parasitoid specificity. This suggests that the chemical(s) involved in host recognition and acceptance by these parasitoids must be specific to the host species involved, as verified in the present study. However, the response of parasitoid females to $\alpha$-amylase is not binomial (yes or no), and becomes more intense with the $\alpha$-amylase of its natural host. Some behavioral responses still occurred with $\alpha$-amylases of unsuitable hosts, nonetheless. The probability of an encounter between $B$. fusca with $C$. flavipes and $C s$-coast, as well as between $C$. partellus with Cs-Inland, is very low, however, due to the different geographical distribution of their respective hosts: $B$. fusca is mostly present in the highlands, whereas C. partellus is mostly found in the lowlands (Mailafiya et al., 2010; Mwalusepo et al., 2015). Such ecological patterns of the host-parasitoid associations suggest that their preference for the $\alpha$-amylase of their host results from adaptation (even recent adaptation, e.g., for C. flavipes toward S. calamistis) to local hosts, as shown for the virulence function for C. sesamiae populations (Dupas et al., 2008; Gauthier et al., 2018).

$\alpha$-Amylases are among the important classes of digestive enzymes used by the insects to hydrolyse starch in various plant tissues to oligosaccharides. Thus, they play a critical role in insect survival by providing energy (Franco et al., 2000). They have also been identified in most insect orders, such as Orthoptera, Hemiptera, Heteroptera, Hymenoptera, Diptera, Lepidoptera, and Coleoptera (Kaur et al., 2014). In Lepidoptera, several $\alpha$-amylase genes commonly occur (e.g., Özgür et al., 2009; Pytelkova et al., 2009; Da Lage et al., 2011). In our study the same enzyme had different isoforms in electrophoresis that exhibited species-specific migration patterns. Since isoform migration distance depends on the molecule electric charge, it is 
Cotesia flavipes

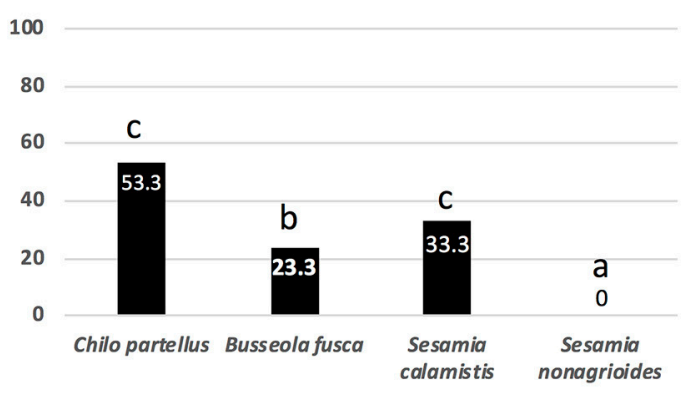

Cotesia sesamiae - Coast

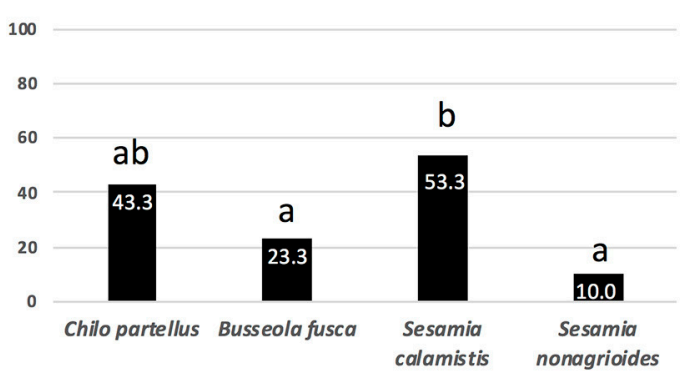

Cotesia sesamiae - Inland

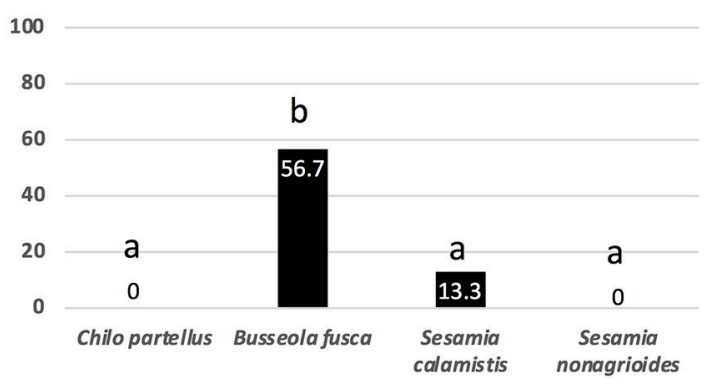

Cotesia typhae

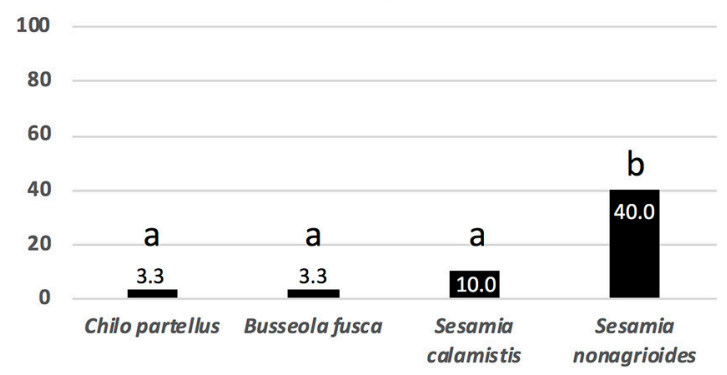

FIGURE 3 | Response of Cotesia flavipes, Cotesia sesamiae-Inland, Cotesia sesamiae-Coast, and Cotesia typhae females to purified $\alpha$-amylase from different host species. The percentages of females $(n=30)$ that exhibited antennation and stinging attempts are given for each bar. After Pearson's Chi-squared test, bars headed with a different letter are significant at a $5 \%$ level according to the Marascuilo procedure (multiple proportions comparison).

not obvious whether different bands represent allelic variation or if they duplicate gene copies. However, in species showing wellseparated groups of bands, such as the two species of Sesamia, it is likely that at least those groups reflect different gene copies. It can be hypothesized that within these species, individuals can express different isoforms of the $\alpha$-amylase. To confirm this hypothesis, it would be necessary to look at the $\alpha$-amylase expression in each individual. Up to now, only one $\alpha$-amylase gene sequence has been identified in $S$. nonagrioides (actually a cDNA; Da Lage J.-L., unpublished study), but given that most Lepidoptera with published genomes harbor several $\alpha$-amylase genes (Da Lage, 2018 for a review), it is quite likely that this is the case in $S$. nonagrioides. Several $\alpha$-amylase gene copies are expressed in a species close to C. partellus, Chilo suppressalis; and three $\alpha$-amylase gene copies in Ephestia kuhniella (Pytelkova et al., 2009). Nevertheless, all these studies indicated that the insects express multiple $\alpha$-amylase at the same time; suggesting that no individual variation in $\alpha$-amylase genes expression might occur within the same species. Therefore, the $\alpha$-amylase gene expression is species-specific.

The two Sesamia species have different ranges of host plants (Le Ru et al., 2006a,b), so genes coding for digestive enzymes like $\alpha$-amylase may have evolved under different selective pressures. Tri-dimensional amylase structures may vary according to the species or even to the isoform if significant sequence differences exist, such as presence or absence of some disulfide bonds, or particular loops (Da Lage et al., 2002). Those structural differences might be discriminated by the sensory equipment of the parasitoid wasp.
For C. flavipes it was shown that it is the conformation of the $\alpha$-amylase rather than its catalytic activity that induces the parasitoid responses (i.e., antennation + stinging attempts; Bichang'a et al., 2018). Therefore, the existence of different $\alpha$-amylase isoforms specific to each stem borer species as shown in Figure 1 corroborates the variable behavioral responses obtained in relation to the host-parasitoid association.

The question arises of how the parasitoids access host $\alpha$ amylase in nature. Lepidopteran stemborer larvae spend their lives and feed inside plant stems. Before entering the feeding tunnel of the host larvae, the wasp first contacts the fecal pellets left by the larvae pushed outside of the stem. These pellets act as a marker of the status of the larva inside the stem tunnel as being host or non-host (Obonyo et al., 2010b), and shows whether they are actively feeding or not. It is most probable that the fecal pellets already contain the stimulatory compounds, since the pellets induced oviposition (Bichang'a et al., 2018). However, the parasitoid is able to definitely recognize the host and accept to oviposit in it only when it is in contact with the host body (Obonyo et al., 2010a,b). We hypothesized that it is during this final step that the parasitoid can confirm the identity of the host larva by detecting the same stimulatory compounds found in the previous fecal pellets and also present on the body of the larva deposited by its feeding activity. These stimulatory compounds need to give quick and appropriate information to the parasitoid on the suitability of the larva (both host and health status) because host larvae often bite the attacking wasps inside the tunnel created by the borer, causing a 50\% mortality risk 
(Takasu and Overholt, 1997). The high selection pressure due to the high mortality at oviposition should favor wasps that can recognize hosts with a minimal risk of injury (Ward, 1992). In this context, the parasitoid response to $\alpha$-amylase needs to be specific to the host involved. In addition, this supposes that the parasitoids can perceive the $\alpha$-amylase through their sensorial equipment.

Obonyo et al. (2010a) observed that female parasitoids use the tip of their antennae to recognize and accept their host larvae for oviposition. They identified the presence of specific sensilla known to have gustatory functions in insects on the last antennal segment (Obonyo et al., 2011). Mailhan (2016) showed that these sensilla chaetica are able to detect the $\alpha$-amylase. However, this result was not confirmed until recently by Tolassy (2018), who suggested that other sensilla from other sensorial organs, such as from the tarsi, might be involved.

There is no physiological evidence that the parasitoid can detect the $\alpha$-amylase, since gustation in insects is known to be influenced generally by small compounds such as sugars, free amino acids and water-soluble alkaloids (Thiéry et al., 2013 for review). Nevertheless, it is well-known that hymenopterans are able to detect large molecules such as long chain cuticular hydrocarbons of more than 60 carbons (Cvacka et al., 2006; Blomquist and Bagnères, 2010) and that non-volatile long-chain hydrocarbons can been detected by olfactory sensilla (Ozaki et al., 2005, 2012). We cannot therefore rule out the detection of $\alpha$-amylase by sensilla specialized in olfaction on Cotesia spp. antennae.

In conclusion, this study shows that $\alpha$-amylase is a key protein for host acceptance and oviposition by species of the C. flavipes complex, and that its variation is involved in the specificity of host-parasitoid association. These findings open new routes for the investigation of evolutionary processes at play in Lepidoptera stem borers-Cotesia and their interactions.

In addition, these findings highlight some issues in biological control perspectives. The ecosystem service provided by biological control relies to a large extent on the natural adaptive abilities of biological control agents. Pest resistance is less frequent in biological control than in chemical control (Holt and Hochberg, 1997). One reason advanced for this better

\section{REFERENCES}

Bichang'a, G. (2018). Host Recognition and Acceptance by Cotesia spp. Kenya: biochemical and molecular aspects. Ph.D. thesis, University of Nairobi, Kenya.

Bichang'a, G., Da Lage, J.-L., Capdevielle-Dulac, C., Zivy, M., Balliau, T., Sambai, K., et al. (2018). $\alpha$-Amylase mediates host acceptance in the braconid parasitoid Cotesia flavipes. J. Chem. Ecol. 44, 1030-1039.

Blomquist, G. J., and Bagnères, A. G. (2010). "Introduction: history and overview of insect hydrocarbons," in Insect Hydrocarbons: Biology, Biochemistry, and Chemical Ecology, eds G. J. Blomquist and A. G. Bagnères (Cambridge: Cambridge University Press), 3-18. doi: 10.1017/CBO978051171190 9.002

Branca, A., Bruno, L. R., Paul-André, C., Julius, O., Boaz, M., Claire, C.-D. et al. (2018). Determinant of genetic structure of the Sub-Saharan parasitic wasp Cotesia sesamiae. bioRxiv [Preprint]. doi: 10.1101/194084

Branca, A., Le Ru, B. P., Vavre, F., Silvain, J.-F., and Dupas, S. (2011). Intraspecific specialization of the generalist parasitoid Cotesia sesamiae revealed by protection against host resistance is that biological control agents can co-evolve and adapt to host resistance, whereas chemical control agents cannot. The link between $\alpha$-amylase isoforms and Cotesia species and population in this study gives a strong insight into such adaptive processes of the parasitoid to its host. In the near future the main relevance in agriculture will be to deliver more efficient parasitoid strains against pest insects. The identification of $\alpha$-amylase's receptors involved in host acceptance mediation will help in targeting the genes of these receptors with the aim of carrying out genetic improvements on them.

\section{AUTHOR CONTRIBUTIONS}

P-AC made conception and design of the study. GB and J-LD contributed to purify and isolate the $\alpha$-amylase. KS performed the bioassays. SM performed the $\alpha$-amylase purifications. P-AC wrote the first draft of the manuscript. GB, J-LD, BL, and LK wrote sections of the manuscript. EM corrected the English. All authors contributed to manuscript revision, read and approved the submitted version.

\section{ACKNOWLEDGMENTS}

The authors wish to thank IRD and ANR ABC PaPoGen (ANR12-ADAP-0001) and ANR CoteBio for funding the research; DAAD for funding the Ph.D. fellowship under the grant number 91560009, the University of Nairobi and the icipe capacity building for hosting the Ph.D. student. Thanks are given to Julius Obonyo and Peter Malusi from icipe for rearing the host insects and the parasitoids; and to François Rebaudo from IRD for his statistical help. Thanks are also given to Fritz Schulthess for reviewing the manuscript.

\section{SUPPLEMENTARY MATERIAL}

The Supplementary Material for this article can be found online at: https://www.frontiersin.org/articles/10.3389/fevo. 2018.00228/full\#supplementary-material

polyDNAvirus polymorphism and associated with different Wolbachia infection. Mol. Ecol. 20, 959-971. doi: 10.1111/j.1365-294X.2010.04977.x

Chng, W. A., Sleiman M. S. B., Schüpfer, F., and Lemaitre, B. (2014). Transforming growth factor $\beta$ /activin signaling functions as a sugar-sensing feedback loop to regulate digestive enzyme expression. Cell. Rep. 9, 336-348. doi: 10.1016/j.celrep.2014.08.064

Cvacka, J., Jiros, P., Sobotník, J., Hanus, R., and Svatos, A. (2006). Analysis of insect cuticular hydrocarbons using matrix-assisted laser desorption/ionization mass spectrometry. J. Chem. Ecol. 32, 409-434. doi: 10.1007/s10886-005-9008-5

Da Lage, J.-L. (2018). The amylases of insects. Int. J. Insect Sci. 10, 1-14. doi: $10.1177 / 1179543318804783$

Da Lage, J.-L., Maczowiak, F., and Cariou, M.-L. (2011). Phylogenetic distribution of intron positions in alpha-amylase genes of Bilateria suggests numerous gains and losses. PLoS ONE 6:e19673. doi: 10.1371/journal.pone.0019673.

Da Lage, J.-L., van Wormhoudt, A., and Cariou, M.-L. (2002). Diversity and evolution of the alpha-amylase genes in Animals. Biologia Bratislava 57, 181-189. 
Dupas, S., Gitau, C. W., Branca, A., Le Rü, B. P., and Silvain, J.-F. (2008). Evolution of a polydnavirus gene in relation to parasitoid-host species immune resistance. J. Hered. 99, 491-499. doi: 10.1093/jhered/esn047

Franco, O. L., Ridgen, D. J., Melo, F. R., Bloch, C. Jr., Silva, C. P., and Grosside-Sa, M. F. (2000). Activity of wheat $\alpha$-amylase inhibitors towards bruchid $\alpha$-amylases and structural explanation of observed specificities. Eur. J. Biochem. 267, 2166-2173. doi: 10.1046/j.1432-1327.2000.01199.x

Gauthier, J., Gayral, P., Le Ru, B. P., Jancek, S., Dupas, S., Kaiser, L., et al. (2018). Genetic footprints of adaptive divergence in the bracovirus of Cotesia sesamiae identified by targeted resequencing. Mol. Ecol. 27, 2109-2123. doi: $10.1111 / \mathrm{mec} .14574$

Gitau, C. W., Schulthess, F., and Dupas, S. (2010). An association between host acceptance and virulence status of different populations of Cotesia sesamiae, a braconid larval parasitoid of lepidopteran cereal stemborers in Kenya. Biol. Control 54, 100-106. doi: 10.1016/j.biocontrol.2010.04.010

Godfray, H. C., Beddington, J. R., Crute, I. R., Haddad, L., Lawrence, D., Muir, J. F., et al. (2010). Food security: the challenge of feeding 9 billion people. Science 327, 812-818. doi: 10.1126/science. 1185383

Godfray, H. C. J. (1994). Parasitoids: Behavioral and Evolutionary Ecology. Princeton: Princeton University Press.

Goftishu, M., Assefa, Y., Fininsa, C., Niba, A., Capdevielle-Dulac, C., and Le $\mathrm{Ru}$, B. P. (2018). Diversity and abundance of lepidopteran stem borers and their host plants in Ethiopia. J. Appl. Entomol. 142, 437-449. doi: 10.1111/jen. 12489

Holt, R. D., and Hochberg, M. E. (1997). When is biological control evolutionarily stable (or is it)? Ecology 78, 1673-1683. doi: 10.1890/00129658(1997)078[1673:WIBCES]2.0.CO;2

Inayatullah, C. (1983). Host selection by Apanteles flavipes (Cameron) (Hymenoptera: Braconidae): influence of host and host plant. J. Econ. Entomol. 76, 1086-1087. doi: 10.1093/jee/76.5.1086

Kaiser, L., Dupas, S., Branca, A., Herniou, E. A., Clarke, C. W., Capdevielle-Dulac, C., et al. (2017b). The Cotesia sesamiae story: insight into host-range evolution in a Hymenoptera parasitoid and implication for its use in biological control programs. Genetica 145, 455-468. doi: 10.1007/s10709-017-9989-3

Kaiser, L., Fernandez-Triana, J., Capdevielle-Dulac, C., Chantre, C., Bodet, M., Kaoula, F., et al. (2017a). Systematic and biology of Cotesia typhae sp. n. (Hymenoptera, Braconidae, Microgastrinae), a potential biological control agent against the noctuid Mediterranean corn borer, Sesamia nonagrioides. ZooKeys 682, 105-136. doi: 10.3897/zookeys.682.13016

Kaur, R., Kaur, N., and Gupta, A. K. (2014). Structural features, substrate specificity kinetic properties of insect $\alpha$-amylase and specificity of plant $\alpha$-amylase inhibitors. Pestic. Biochem. Physiol. 116, 83-93. doi: 10.1016/j.pestbp.2014.09.005

Kfir, R. (1995). Parasitoids of the African stemborer Busseola fusca (Lepidoptera: Noctuidae) in South Africa. Bull. Entomol. Res. 85, 369-377. doi: $10.1017 /$ S0007485300036105

Kfir, R., Overholt, W. A., Khan, Z. R., and Polaszek, A. (2002). Biology and management of economically important lepidopteran cereal stemborers in Africa. Annu. Rev. Entomol. 47, 701-731. doi: 10.1146/annurev.ento.47.091201.145254

Lazarovitz, G., Goettel, S., and Vincent, C. (2007). "Adventures in biological control," in Biological Control: A Global Perspective: Case Studies from Around the World, eds C. Vincent, S. Goettel, and G. Lazarovitz, (Wallingford: CABI), $1-6$.

Le Ru, B. P., Ong’amo, G. O., Moyal, P., Muchugu, E., Ngala, L., Musyoka, B., et al. (2006a). Geographic distribution and host plant ranges of East African noctuid stem borers. Ann. Soc. Entomol. Fr. 42, 353-361. doi: 10.1080/00379271.2006.10697467

Le Ru, B. P., Ong'amo, G. O., Moyal, P., Ngala, L., Musyoka, B., Abdullah, Z., et al. (2006b). Diversity of lepidopteran stemborers on monocotyledonous plants in eastern Africa and island of Madagascar and Zanzibar revisited. Bull. Entomol. Res. 96, 555-563. doi: 10.1079/BER2006457

Lewis, W. J., and Martin, W. R. Jr. (1990). Semiochemicals for use with parasitoids: status and future. J. Chem. Ecol. 16, 3067-3089. doi: 10.1007/BF00979613

Loyter, A., and Schramm, M. (1962). Charcoal-celite column. Biochim. Biophys. Acta 65, 200-206. doi: 10.1016/0006-3002(62)91039-9

Mailafiya, D. M., Le Ru, B. P., Kairu, E. W., Calatayud, P.-A., and Dupas, S. (2009). Species diversity of lepidopteran stem borer parasitoids in cultivated and natural habitats in Kenya. J. Appl. Entomol. 133, 416-429. doi: 10.1111/j.1439-0418.2009.01381.x

Mailafiya, D. M., Le Ru, B. P., Kairu, E. W., Calatayud, P.-A., and Dupas, S. (2010). Geographic distribution, host range and perennation of Cotesia sesamiae and Cotesia flavipes Cameron in cultivated and natural habitats in Kenya. Biol. Control 54, 1-8. doi: 10.1016/j.biocontrol.2009.11.008

Mailhan, C.-M. (2016). Une $\alpha$-Amylase de L'hôte est-elle Détectée par le Système Gustatif d’un Hyménoptère Parasitoide lors de Ses Processus de Reconnaissance? Master Report, SupAgro, Montpellier, France.

Marascuilo, L. (1966). Large-sample multiple comparisons. Psychol. Bull. 65, 289-299. doi: 10.1037/h0023189

Mochiah, M. B., Ngi-Song, A. J., Overholt, W. A., and Stouthamer, R. (2002). Variation in encapsulation sensitivity of Cotesia sesamiae biotypes to Busseola fusca. Entomol. Exp. Appl. 105, 11-118. doi: 10.1046/j.1570-7458.2002.0 1039.x

Mohyuddin, A. I., Inayatullah, C., and King, E. G. (1981). Host selection and strain occurrence in Apanteles flavipes (Cameron)(Hymnoptera: Braconidae) and its rearing on biological control of graminaceous stem-borers (Lepidoptera: Pyralidae). Bull. Entomol. Res. 71, 575-581. doi: 10.1017/S0007485300010087

Moolman, J., Van den Berg, J., Conlong, D., Cugala, D., Siebert, S., and Le Ru, B. (2014). Species diversity and distribution of lepidopteran stem borers in South Africa and Mozambique. J. Appl. Entomol. 138, 52-66. doi: 10.1111/jen.12085

Muirhead, K. A., Murphy, N. P., Sallam, N., Donnellan, S. C., and Austin, A. D. (2012). Phylogenetics and genetic diversity of the Cotesia flavipes complex of parasitoid wasps (Hymenoptera: Braconidae), biological control agents of lepidopteran stemborers. Mol. Phylogenet. Evol. 63, 904-914. doi: 10.1016/j.ympev.2012.03.003

Mwalusepo, S., Tonnang, H. E., Massawe, E. S., Okuku, G. O., Khadioli, N., Johansson, T., et al. (2015). Predicting the impact of temperature change on the future distribution of maize stem borers and their natural enemies along East African mountain gradients using phenology models. PLoS ONE 10: e0130427. doi: 10.1371/journal.pone.0130427

Nagaraju, J., and Abraham, E. G. (1995). Purification and characterization of digestive amylase from the tasar silkworm, Antheraea mylitta (Lepidoptera : Saturniidae). Comp. Biochem. Physiol. 110, 201-209. doi: 10.1016/0305-0491(94)00121-A

Ngi-Song, A. J., Overholt, W. A., and Ayertey, J. N. (1995). Suitability of African gramineous stemborers for development of Cotesia flavipes and C. sesamiae (Hymenoptera: Braconidae). Environ. Entomol. 24, 978-984. doi: $10.1093 / \mathrm{ee} / 24.4 .978$

Ngi-Song, A. J., Overholt, W. A., Njagi, P. G., Dicke, M., Ayertey, J. N., and Lwande, W. (1996). Volatile infochemicals used in host habitat location by Cotesia flavipes Cameron and Cotesia sesamiae (Cameron) (Hymenoptera: Braconidae), larval parasitoids of stemborers on graminae. J. Chem. Ecol. 22, 307-323. doi: 10.1007/BF02055101

Niepmann, M., and Zheng, J. (2006). Discontinuous native protein gel electrophoresis. Electrophoresis 27, 3949-3951. doi: 10.1002/elps.200600172

Obonyo, M., Schulthess, F., Chimtawi, M., Mascarel, G., Ahuya, P. O., $\mathrm{Le} \mathrm{Ru}, \mathrm{B}$., et al. (2011). Sensilla on antennae, ovipositor and tarsi of the larval parasitoids, Cotesia sesamiae (Cameron 1906) and Cotesia flavipes Cameron 1891 (Hymenoptera: Braconidae): a comparative scanning electron microscopy study. Ann. Soc. Entomol. Fr. 47, 119-127. doi: 10.1080/00379271.2011.10697703

Obonyo, M., Schulthess, F., Gerald, J., Wanyama, O., Le Ru, B., and Calatayud, P.-A. (2008). Location, acceptance and suitability of lepidopteran stemborers feeding on a cultivated and wild host-plant to the endoparasitoid Cotesia flavipes Cameron (Hymenoptera: Braconidae). Biol. Control 45, 36-47. doi: 10.1016/j.biocontrol.2007.11.010

Obonyo, M., Schulthess, F., Le Ru, B., Van Den Berg, J., and Calatayud, P.A. (2010a). Host recognition and acceptance behaviour in Cotesia sesamiae and C. flavipes (Hymenoptera: Braconidae), parasitoids of gramineous stemborers in Africa. Eur. J. Entomol. 107, 169-176. doi: 10.14411/eje.20 10.022

Obonyo, M., Schulthess, F., Le Ru, B., Van Den Berg, J., Silvain, J.-F., and Calatayud, P.-A. (2010b). Importance of contact chemical cues in host recognition and acceptance by the braconid larval endoparasitoids Cotesia sesamiae and Cotesia flavipes. Biol. Control 54, 270-275. doi: $10.1016 /$ j.biocontrol.2010.05.015 
Ochieng, R. S., Onyango, F. O., and Bungu, M. D. O. (1985). Improvement of techniques for mass culture of Chilo partellus (Swinhoe). Insect Sci. Appl. 6, 425-428. doi: 10.1017/S17427584000 04744

Ong'amo, G. O., Le Gall, P., and Ndemah, R., Le Ru, B. P. (2014). Diversity and host range of lepidopteran stem borer species in Cameroon. Afr. Entomol. 22, 625-635. doi: 10.4001/003.022.0316

Onyango, F. O., and Ochieng'-Odero, J. P. R. (1994). Continuous rearing of the maize stemborer Busseola fusca on an artificial diet. Entomol. Exp. Appl. 73, 139-144.

Overholt, W. A., Ochieng, J. O., Lammers, P. M., and Ogedah, K. (1994a). Rearing and field release methods for Cotesia flavipes Cameroon (Hymenoptera: Braconidae), a parasitoid of tropical gramineous stemborers. Insect Sci. Appl. $15,253-259$.

Overholt, W. A., Ogedah, K., and Lammers, P. M. (1994b). Distribution and sampling of Chilo partellus (Lepidoptera: Pyralidae) in maize and sorghum on the Kenya coast. Bull. Entomol. Res. 84, 367-378. doi: 10.1017/S0007485300032491

Ozaki, M., Kidokoro-Kobayashi, M., and Hiraguchi, T. (2012). "Cuticular hydrocarbons sensillum for nestmate recognition in ants," in Frontiers in Sensing: From Biology to Engineering, eds F. G. Barth, J. A. C. Humphrey, and M. V. Srinivasan (Wien, NewYork, NY: Springer), 145-158. doi: 10.1007/978-3-211-99749-9_10

Ozaki, M., Wada-Katsumata, A., Fujikawa, K., Iwasaki, M., Yokohari, F., Satoji, Y., et al. (2005). Ant nestmate and non-nestmate discrimination by a chemosensory sensillum. Science 309, 311-314. doi: 10.1126/science.11 05244

Özgür, E., Yücel, M., and Öktem, H. A. (2009). Identification and characterization of hydrolytic enzymes from the midgut of the cotton bollworm, Helicoverpa armigera Hübner (Lepidoptera: Noctuidae). Turk. J. Agric. For. 33, 285-294. doi: 10.3906/tar-0802-5

Pimentel, D., Acquay, H., Biltonen, M., Rice, P., Silva, M., Nelson, J., et al. (1992). Environmental and economic costs of pesticide use. BioScience 42, 50-760.

Potting, R. P. J., Osane-Danso, F., Overholt, W. A., and Ngi-Song, A. J. (1993). "Host selection in Cotesia flavipes parasitoid of tropical stemborers," in Proceedings Experimental and Applied Entomology (N.E.V, Amsterdam) 4, 47-62.

Potting, R. P. J., Vet, L. E. M., and Dicke, M. (1995). Host microhabitat location by stemborer parasitoid Cotesia flavipes: the role of herbivore volatiles and locally and systemically induced plant volatiles. J. Chem. Ecol. 21, 525-539. doi: 10.1007/BF02033699

Pytelkova, J., Hubert, J., Lepsik, M., Sobotnik, J., Sindelka, R., and Krizkova, I. (2009). Digestive $\alpha$-amylases of the flour moth Ephestia kuehniella-adaptation to alkaline environment and plant inhibitors. FEBS J. 276, 3531-3546. doi: 10.1111/j.1742-4658.2009.07074.x

Quicke, D. L. (1997). Parasitic Wasps. The Netherlands: Springer.
Röse, U. S. R., Alborn, H. T., Makranczy, G., Lewis, W. J., and Tumlinson, J. H. (1997). Host recognition by the specialist endoparasitoid Microplitis croceipes: role of host and plant related volatiles. J. Insect Behav. 10, 313-329. doi: 10.1007/BF02765600

Schrambach, A., and Jovin, T. M. (1983). Selected buffer systems for moving boundary electrophoresis on gels at various $\mathrm{pH}$ values, presented in a simplified manner. Electrophoresis 4, 190-204. doi: 10.1002/elps.1150040303

Takasu, K., and Overholt, W. A. (1997). Aggressive behaviour of Chilo partellus (Swinhoe) larvae against the parasitoid Cotesia flavipes Cameron. Insect Sci. Appl. 17, 131-136. doi: 10.1017/S1742758400022244

Thiéry, D., Derridj, S., Calatayud, P.-A., Nevile, M., and Marion-Poll, F. (2013). "Linsecte au contact des plantes," in dans Interactions Insectes - plantes, eds N. Sauvion, P.-A. Calatayud, D. Thiéry, and F. Marion-Poll (Paris: Co-édition IRD-Quae), 347-368

Tilman, D., Fargione, J., Wolff, B., D’Antonio, C., Dobson, A., Howarth, R., et al. (2001). Forecasting agriculturally driven global environmental change. Science 292, 281-284. doi: 10.1126/science.1057544

Tolassy, V. (2018). Validation d'une réponse gustative à l'alpha-amylase chez Drosophila melanogaster et Cotesia flavipes. Master Report, Université Paul Sabatier, Toulouse III, France.

Van Leerdam, M. B., Smith, J. W. Jr., and Fuchs, T. W. (1985). Frass-mediated, host finding behaviour of Cotesia flavipes, a braconid parasite of Diatraea saccharalis (Lepidoptera: Pyralidae). Ann. the Entomol. Soc. Am. 78, 647-650. doi: $10.1093 /$ aesa/78.5.647

Vet, L. E. M. (1999). From chemical to population ecology: infochemical use in an evolutionary context. J. Chem. Ecol. 25, 31-49. doi: 10.1023/A:1020833015559

Vinson, S. B. (1991). Chemical signals used by parasitoids. Redia 74, 15-42.

Wajnberg, E., Bernstein, C., and Van Alphen, J. (2008). Behavioral of Ecology of Insect Parasitoids. Oxford: Blackwell Publishing. doi: 10.1002/9780470696200

Wajnberg, E., and Colazza, S. (2013). Chemical Ecology of Insect Parasitoids. West Sussex; Oxford: Whiley-Blackwell, A John Wiley \& Sons, Ltd., Publication.

Ward, S. A. (1992). Environmental uncertainty and polyphagy in herbivorous insects. Oikos 63, 506-512. doi: 10.2307/3544978

Conflict of Interest Statement: The authors declare that the research was conducted in the absence of any commercial or financial relationships that could be construed as a potential conflict of interest.

Copyright (c) 2018 Bichang'a, Da Lage, Sambai, Mule, Le Ru, Kaiser, Juma, Maina and Calatayud. This is an open-access article distributed under the terms of the Creative Commons Attribution License (CC BY). The use, distribution or reproduction in other forums is permitted, provided the original author $(s)$ and the copyright owner(s) are credited and that the original publication in this journal is cited, in accordance with accepted academic practice. No use, distribution or reproduction is permitted which does not comply with these terms. 